\title{
Evaluation of Chromium Carbide Coatings on AISI 52100 Steel Obtained by Thermo-Reactive Diffusion Technique
}

\author{
Xiaoming ZONG, Wenming JIANG *, Zitian FAN
}

State Key Lab of Materials Processing and Die \& Mould Technology, Huazhong University of Science and Technology, Wuhan 430074, Hubei, China

crossref http://dx.doi.org/10.5755/j01.ms.25.1.19094

Received 20 September 2017; accepted 13 January 2018

In this study, chromium carbide coating obtained by thermo-reactive diffusion (TRD) process on AISI 52100 steel, prepared by packed method at temperature of $850^{\circ} \mathrm{C}$ for $2,4,6$ and $8 \mathrm{~h}$, were investigated by performing a series of tests. The chromium carbide coating was characterized by scanning electron microscopy, X-ray diffraction (XRD), Micro-Vickers hardness test and Daimler-Benz Rockwell-C adhesion test. The chromium carbide layer produced on the AISI52100 steel exhibited a smooth and flat morphology. Depending on treatment time, the coating had a thickness of $3.2-8.5 \mu \mathrm{m}$. XRD analysis revealed the existence of $\mathrm{Cr}_{7} \mathrm{C}_{3}$ and $(\mathrm{Cr}, \mathrm{Fe})_{7} \mathrm{C}_{3}$ compounds. The hardness of the surface was increased from 723 to $1730-1920 \mathrm{HV}_{0.025}$ after the coating process. The adhesion strength quality of the coating is correlated to HF2 to HF3 according to the VDI 3198 norm. Comparision of wear performance between chromium carbide coating and substrate showed that the coating can significantly improve wear resistance of the material. Friction coefficient decreased from the 0.46 to 0.37 and wear weight loss decreased by $89.3 \%$.

Keywords: chromium carbide coating, thermo-reactive diffusion, AISI 52100 steel, adhesion, tribological behaviour.

\section{INTRODUCTION}

Ceramic coatings are very effective for increasing the service life of machine components, cutting and forming tools, with improved corrosion and wear resistance [1-3]. These ceramics mainly comprise transition metal carbides and nitrides [4]. As one of the most widely used ceramic coatings, chromium carbide coatings have been extensively used as protective coating on various tools, dies and sliding bearing mainly due to its high resistance to wear, corrosion and oxidation and its high hardness $[5,6]$.

Chemical vapor deposition (CVD) and physical vapor deposition (PVD) have been applied to fabricating thin hard coating by industries worldwide [7-10]. Moreover, the thermo-reactive diffusion (TRD) technique has also been used for the hard coatings of carbide, nitride or boride on iron base alloys [11]. Actually, TRD is simpler, environmental friendly and cost-effective relative to other coating processes. High quality ceramic coatings can be produced by TRD with good hardness, adhesion, toughness and heat resistance properties [12].

In TRD process, a substrate is either immersed into a molten borax bath (salt bath immersion method) or covered with a mixture of powders (powder-pack method) which contains carbide/nitride forming elements (CFE/NFE) such as tantalum, chromium, tungsten, molybdenum, vanadium and niobium [13]. The coating is formed by the combination of carbide/nitride forming elements with the carbon/nitrogen diffused from the substrate to the surface and the thickness of the coating can be significantly affected by exposure time and temperature, and kinds of carbide and substrate steel [14].

\footnotetext{
* Corresponding author. Tel.: +86-18303696584.

E-mail address: jwenming@163.com (W.M. Jiang)
}

Despite the potential advantages above mentioned, the application of TRD technology is not extensive, and there is limited scientific literature about it when compared with other deposition methods. Chromium carbide coatings were formed on various kinds of steels, emphasizing on their anti-oxidation and anti-corrosion properties [15]. Moreover, there have been some studies on the microstructure and growth kinetics of chromium carbide coating on steels [16]. Nevertheless, few studies have centered on adhesion and tribological properties of the chromium carbide layers, especially on bearing steels. In this study, AISI 52100 steel, which is well known as bearing steel was used as substrate.

Adhesion is an important performance index for evaluating the reliability of coated components. Coating adhesion can be influenced by many parameters such as coating stress, pollution, coating/substrate chemical bonding, and the physical characteristics and roughness of the substrate [17]. There are several ways of determining coating adhesion, such as scratch test, pull-off test and Rockwell test [18]. The well-known Rockwell-C indentation test, prescribed by the VDI 3198 norm, is a destructive quality test for coated compounds [19].

The purpose of this research was to study chromium carbide coatings produced by TRD technique on the AISI 52100 steel samples. The microstructure, phases and microhardness were investigated using a scanning electron microscope, X-Ray diffraction and Vickers indenter. In addition, adhesion and tribological properties were also investigated.

\section{MATERIALS AND METHODS}

\subsection{Materials and process}

Table 1 lists the chemical composition of the substrate known as a ball-bearing steel with high carbon content. 
The sample was cut into pieces $(20 \mathrm{~mm}$ diameter, $5 \mathrm{~mm}$ length) before treatment, ground up to 1000 grid emery paper, and thereafter rinsed ultrasonically in ethyl alcohol.

Chromium carbide coating was produced on the steel with the pack method in the blend consisting of ferrochromium, $\mathrm{NH}_{4} \mathrm{Cl}$ and $\mathrm{NaF}$. The TRD treatment was performed in a steel box sealed with alumina-based cement at $850{ }^{\circ} \mathrm{C}$ in an electrical resistance furnace for 2 , 4,6 and $8 \mathrm{~h}$, and followed by cooling with furnace to $150{ }^{\circ} \mathrm{C}$. After TRD treatment, all the samples were heated $\left(650{ }^{\circ} \mathrm{C}\right.$ for $\left.20 \mathrm{~min}\right)$, austenitized $\left(840{ }^{\circ} \mathrm{C}\right.$ for $20 \mathrm{~min}$, oil quenched), cryogenic treatment $\left(-78^{\circ} \mathrm{C}\right.$ for $\left.1 \mathrm{~h}\right)$, and lowtemperature heat treatment $\left(160{ }^{\circ} \mathrm{C}\right.$ for $\left.2 \mathrm{~h}\right)$ to generate the desirable tempered martensite structure.

Table 1. Chemical composition of the substrate steel AISI 52100

\begin{tabular}{|c|c|c|c|c|c|c|c|c|c|}
\hline Element & $\mathrm{C}$ & $\mathrm{Cr}$ & $\mathrm{Ni}$ & $\mathrm{Si}$ & $\mathrm{Mn}$ & $\mathrm{Mo}$ & $\mathrm{S}$ & $\mathrm{P}$ & $\mathrm{Fe}$ \\
\hline wt.\% & 0.95 & 1.45 & 0.11 & 0.19 & 0.32 & 0.01 & 0.01 & 0.01 & Balance \\
\hline
\end{tabular}

\subsection{Characterization}

The microstructures were observed under a QUAN TA-400 scanning electron microscope (SEM). The presence of chromium carbide coating was confirmed by X-ray diffraction (XRD, Shimadzu, Japan) with $2 \theta$ varying from $20^{\circ}$ to $90^{\circ}$ using $\mathrm{Cu} \mathrm{K} \alpha$ radiation. The distribution of the alloying elements within the chromium carbide layer was determined by means of electron dispersive spectroscopy (EDS) (LEO-1430VP, Oberkochen, Germany) from the surface to the interior. The hardness measurements were made using a HXD1000 Vickers indenter with a load of $0.245 \mathrm{~N}$. The thickness of the layer was measured with a digital thickness measurement instrument attached to the SEM. Thickness values are reported as the averages of at least 10 measurements.

\subsection{Rockwell-C adhesion properties}

The Daimler-Benz Rockwell-C adhesion test was applied to the assessment of the adhesion of the chromium carbide layers. The principle of this approach is shown in Fig.1. A load of $1471 \mathrm{~N}$ was used to cause coating destruction adjacent to the indentation boundary [19]. Three indentations were performed for each sample and SEM was used to evaluate the test.

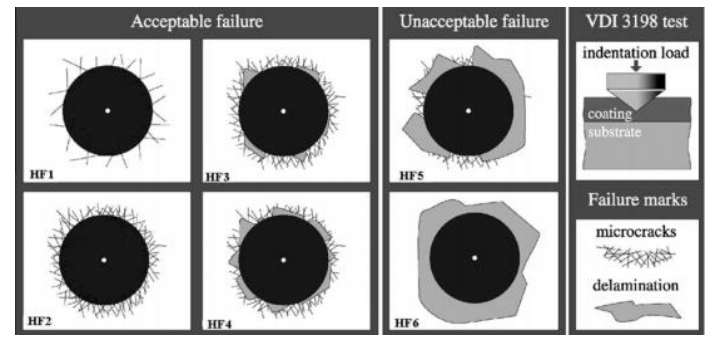

Fig. 1. The principle of the VDI 3198 indentation test

\subsection{Wear test}

Tribological properties of the chromium carbide coatings were examined using a pin-on-disc test device. The samples were rotated at a speed of $0.3 \mathrm{~m} / \mathrm{s}$ under a load of $15 \mathrm{~N}$, and the sliding time was $30 \mathrm{~min}$ for each test. The pin is a $\mathrm{Si}_{3} \mathrm{~N}_{4}$ ceramic ball with a diameter of $6 \mathrm{~mm}$.
The specimens were cleaned before and after the tests by immersion in acetone with agitation in an ultrasonic bath for $15 \mathrm{~min}$. Untreated AISI 52100 steel was submitted to wear tests in a quenched and tempered condition with the hardness of $61 \mathrm{HRC}$. Wear tests were carried out in the unlubricated condition at room temperature in open air. The friction force was detected by a load cell through a friction force measurement arm. The friction coefficient was continuously recorded during the tests. Surface profiles of the wear tracks on the disks were measured by a surface profilometer. Wear volume of the disk specimen was determined from the cross-sectional area of the wear track obtained perpendicularly to the sliding direction. The wear rates of coatings were calculated according to:

$K=\frac{V}{p \cdot s}$,

where, $K$ is the relative wear rate $\left(\mathrm{mm}^{3} / \mathrm{N} . \mathrm{m}\right), V$ is the wear volume, $p$ is the load and $\mathrm{s}$ is the sliding distance. Two wear experiments were conducted for each sample and three measurements were performed using the surface profilometer each wear track and the average value is reported. Worn surfaces were investigated by optical microscope, SEM and electron dispersive spectroscopy (EDS).

\section{RESULTS AND DISCUSSION}

\subsection{Characterization of chromium carbide coating}

Fig. 2 shows the SEM micrograph of cross-section of chromium carbide-coated AISI52100 steel after the TRD treatment $\left(850^{\circ} \mathrm{C}, 2\right.$ and $\left.8 \mathrm{~h}\right)$.
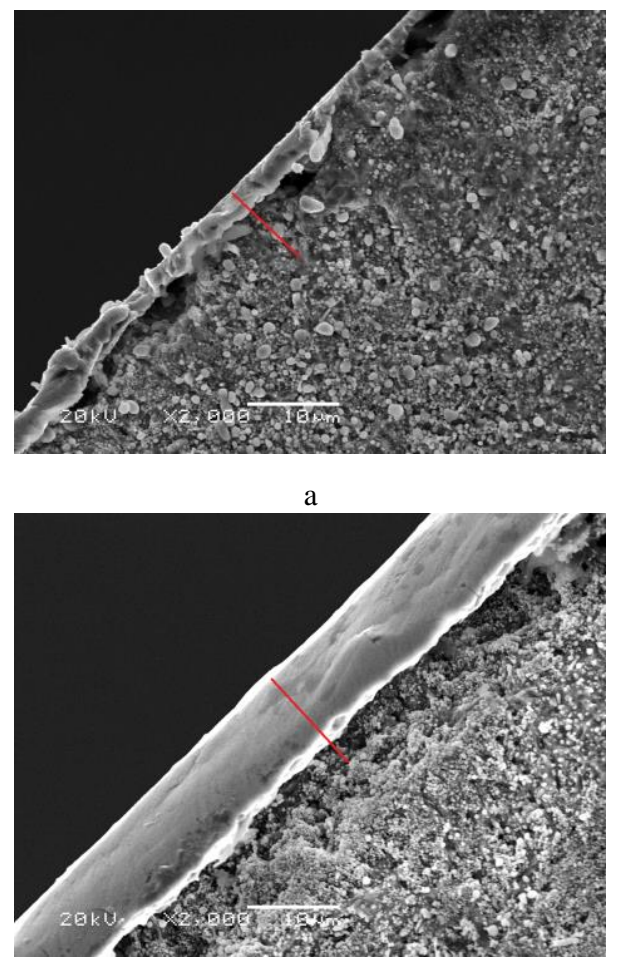

$\mathrm{b}$

Fig. 2. SEM micrograph of the AISI 52100 steel, coated with chromium carbide at $850^{\circ} \mathrm{C}: \mathrm{a}-2 \mathrm{~h} ; \mathrm{b}-8 \mathrm{~h}$ 
As shown, the chromium carbide layer produced on the AISI52100 steel exhibited a smooth and flat morphology. There is a distinct, flat interface zone between the chromium carbide coating and the substrate. This zone can be divided into chromium carbide layer and steel matrix. The SEM micrograph also reveals that chromium carbide layer formed on the steel surface has uniform thickness throughout the surface and the coating layer.

Element distribution along the line shown in Fig. 2 a and $b$ are present in Fig. 3. As can be seen from the EDS line scan profiles, an obvious chromium-iron coexistence zone can be pointed out in samples. Actually, the iron content increases slowly moving from the surface to the core of the sample, and iron and chromium have a wide coexistence zone. The effect may be attributed to relatively high (compared with other carbide forming elements, such as V) solubility product of chromium and carbon in austenite at TRD temperature [20]. This phenomenon especially occurred at the first period of TRD process (prior to the ceramic coating formation). Subsequently, during the cooling process, chromium precipitated as carbide because of the decreased solubility product.

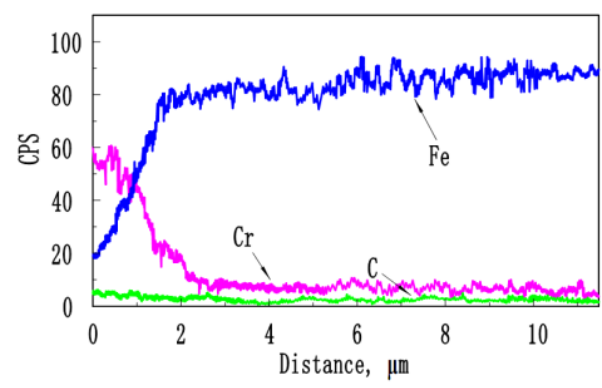

a

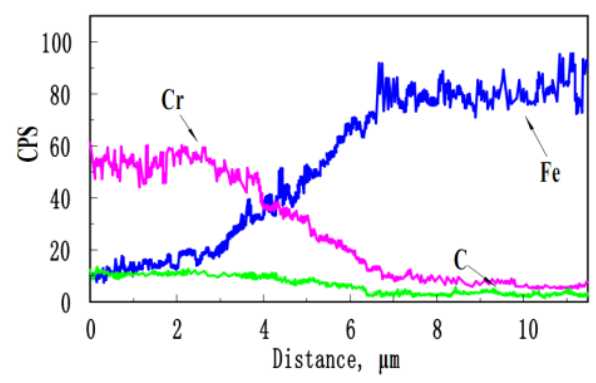

b

Fig. 3. EDS analysis results of the AISI 52100 steel, coated with chromium carbide at $850{ }^{\circ} \mathrm{C}: \mathrm{a}-2 \mathrm{~h} ; \mathrm{b}-8 \mathrm{~h}$

\subsection{XRD analysis}

In this work, the presence of chromium carbides was identified by using XRD analysis (Fig. 4). As shown, the presence of $\mathrm{Cr}_{7} \mathrm{C}_{3}$ and $(\mathrm{Cr}, \mathrm{Fe})_{7} \mathrm{C}_{3}$ was detected. With increasing of treatment time, $\mathrm{Cr}_{7} \mathrm{C}_{3}$ content increases and $(\mathrm{Cr}, \mathrm{Fe})_{7} \mathrm{C}_{3}$ phase decreases for AISI 52100 steel. The properties of the chromium carbide layers are determined by the phase structure.

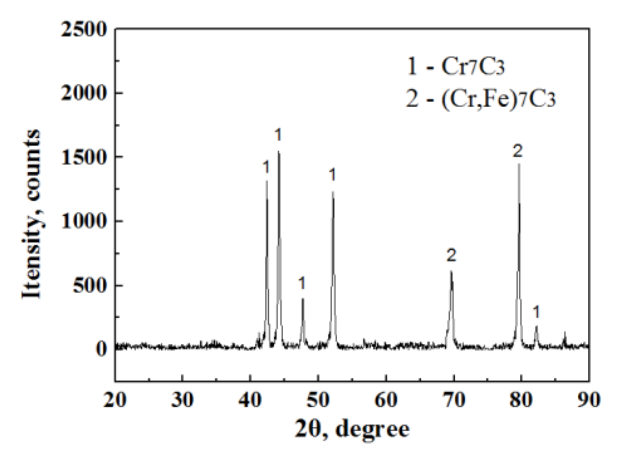

a

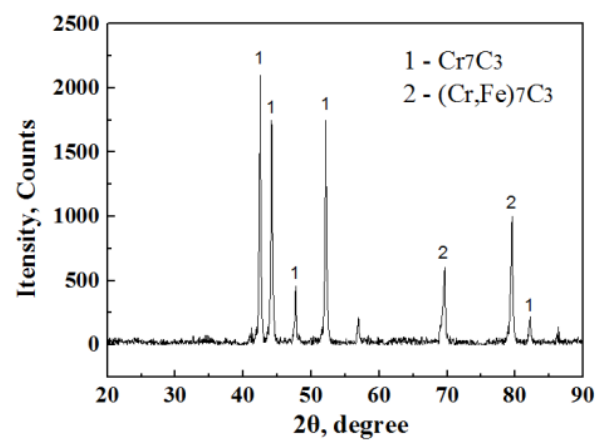

b

Fig. 4. XRD patterns of the AISI 52100 steel, coated with chromium carbide at $850{ }^{\circ} \mathrm{C}: \mathrm{a}-2 \mathrm{~h} ; \mathrm{b}-8 \mathrm{~h}$

\subsection{Thickness and hardness of chromium carbide layer}

The measured thickness values of the chromium carbide layer are in the range of $3.2-8.5 \mu \mathrm{m}$. Fig. 5 a shows that the thickness of chromium carbide layer increased with time at $850{ }^{\circ} \mathrm{C}$. There is a nearly parabolic relation between the depth of chromium carbide layer and diffusion time. The thickness was in directly proportional to the square root of time in hour (Fig. 5 b).

The microhardness of outer layer surface formed after TRD treatment ranged from 1730 to $1920 \mathrm{HV}_{0.025}$. These values are considerably higher than that of the substrate $\left(723 \mathrm{HV}_{0.025}\right)$. This is because of the presence of hard $\mathrm{Cr}_{7} \mathrm{C}_{3}$ and $(\mathrm{Cr}, \mathrm{Fe})_{7} \mathrm{C}_{3}$ phase in the coating layer, providing an extremely hard surface. In thermo-reactive diffusion treatment, high hardness is obtained directly through the generation of transition metal carbides.

Fig. 6 shows the microhardness versus distance from the surface of the sample to the core produced at $850{ }^{\circ} \mathrm{C}$ on AISI 52100 steel with treatment time of $2 \mathrm{~h}, 4 \mathrm{~h}, 6 \mathrm{~h}$ and $8 \mathrm{~h}$. As can be seen, for the treatment times of $4 \mathrm{~h}, 6 \mathrm{~h}$ and $8 \mathrm{~h}$, the hardness distribution from the surface to the substrate gradually varies. With the treatment time of $2 \mathrm{~h}$, the cross section hardness near the surface of the chromium carbide layer is difficult to obtain due to its excessive thin thickness, so the measurement result is much lower than that of the surface layer.

\subsection{Rockwell-C adhesion properties}

SEM micrographs of the indentation craters for TRD treated sample with treatment time of $2 \mathrm{~h}$ and $8 \mathrm{~h}$ are given in Fig. 7. 


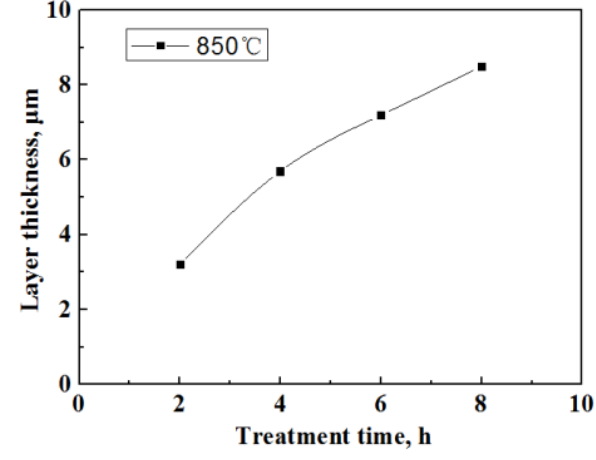

a

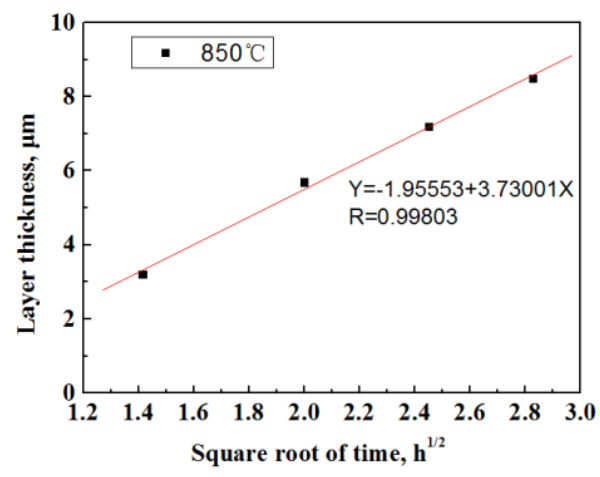

b

Fig. 5. The thickness of chromium carbide layer as a function of: $a$-treatment time; $b$-square root of treatment time

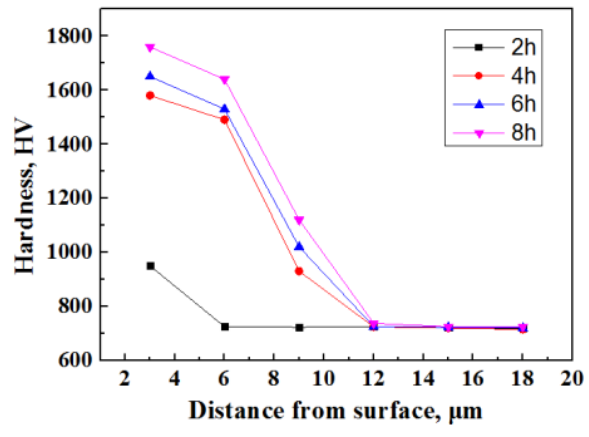

Fig. 6. The variation of microhardness versus distance from the surface of the sample to the core produced at $850{ }^{\circ} \mathrm{C}(2 \mathrm{~h}$, $4 \mathrm{~h}, 6 \mathrm{~h}, 8 \mathrm{~h}$ treatment) on AISI 52100 steel

There were little flaking areas at the perimeter of indentation craters as well as radial crackings, and these failures represent $\mathrm{HF} 2$ type of the adhesion strength quality. In general, the adhesion strength quality maps HF1-HF4 define sufficient adhesion, whereas HF5 and HF6 represent insufficient adhesion [19], so there was sufficient adhesion of the chromium carbide layers on AISI 52100 steel.

\subsection{Tribological properties}

Fig. 8 shows the variation of the friction coefficients of the AISI 52100 substrate and chromium carbide layer $\left(850^{\circ} \mathrm{C}\right.$ for $\left.8 \mathrm{~h}\right)$ sliding against $\mathrm{Si}_{3} \mathrm{~N}_{4}$ ball under dry friction condition. In the first stage of the friction test, the coefficients of friction of both samples increase with the sliding time rapidly. At the steady-state, the coefficients of friction of the substrate and the chromium carbide layer are 0.46 and 0.37 respectively.

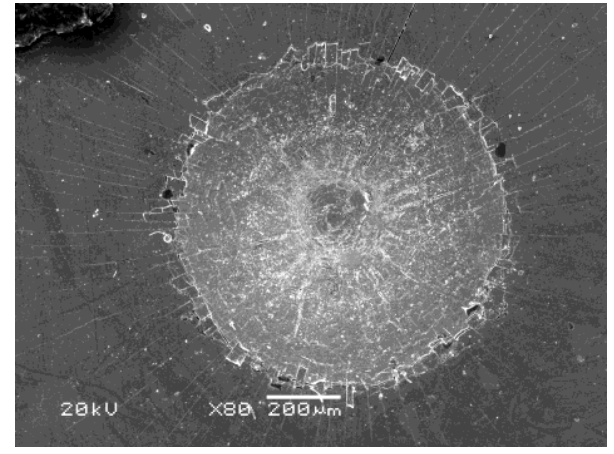

a

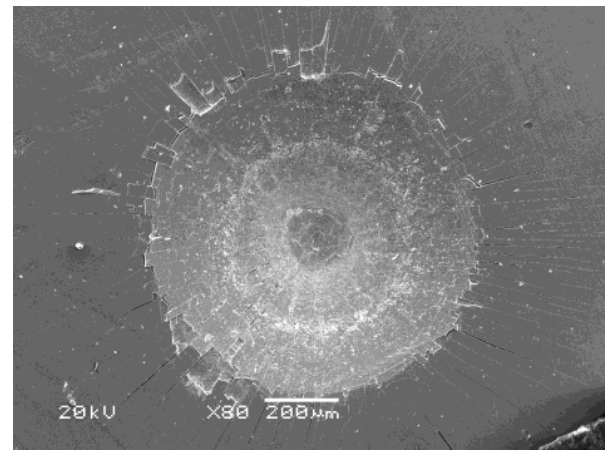

b

Fig. 7. Rockwell-C indentation craters for the AISI 52100 steel, coated with chromium carbide at $850{ }^{\circ} \mathrm{C}: \mathrm{a}-2 \mathrm{~h} ; \mathrm{b}-8 \mathrm{~h}$

Apparently, the coefficient of friction of the chromium carbide layer decreased significantly and the change tendency of coefficient of friction becomes smoother than that of the AISI52100 substrate. The friction coefficient of chromium carbide layer presents no abrupt change, which indicates the surface of $\mathrm{Cr}$ modified layer exists no or less brittle oxidation and has no wornout occurred.

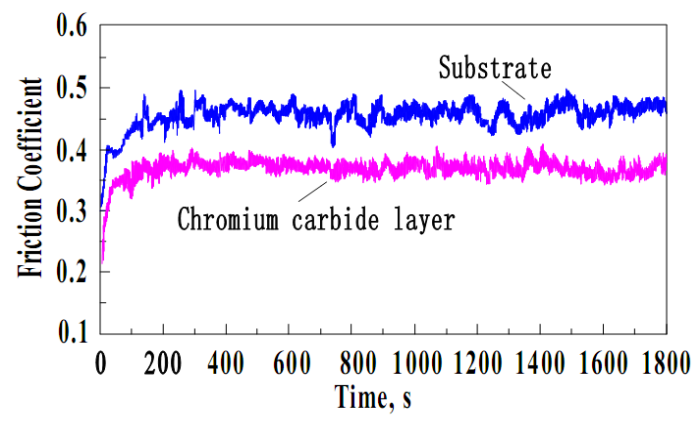

Fig. 8. Curve of friction coefficient versus sliding time

Fig. 9 and Fig. 10 show the worn surface morphologies of AISI 52100 substrate and TRD treated samples, respectively. As shown in Fig. 9 a and Fig. 10 a, the wear scar width of substrate and TRD treated samples are about $580 \mu \mathrm{m}$ and $210 \mu \mathrm{m}$ respectively. Obviously, the wear resistance of chromium carbide layer is superior to that of substrate. As shown in Fig. 9 b and Fig. 10 b, the worn surface morphologies of the substrate and chromium carbide layer exhibit different characteristics, which can reveal different mechanisms of wear. 


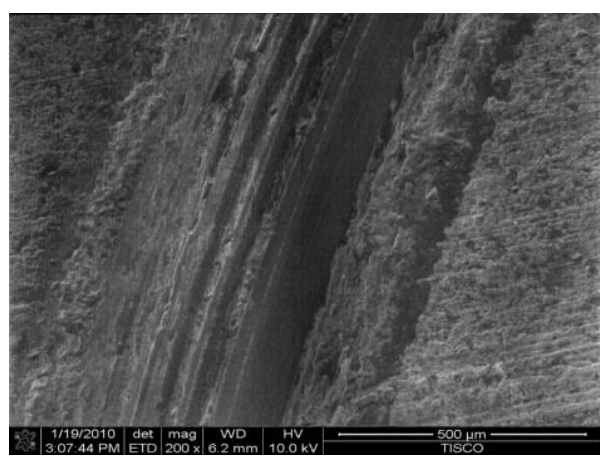

a

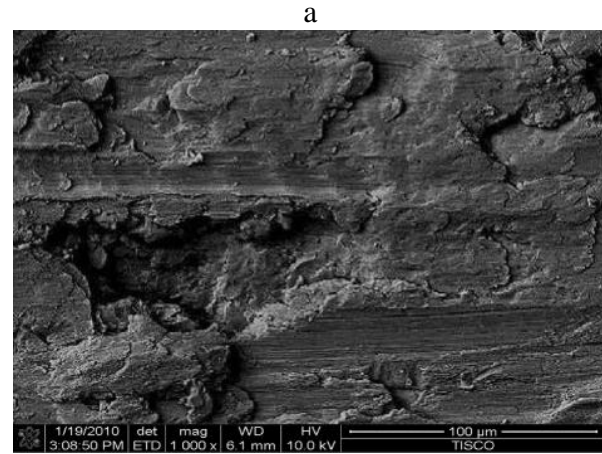

b

Fig. 9. Wear track of AISI 52100 steel substrate: a-wear scar morphology of specimen; $b$ - micrograph of wear surface

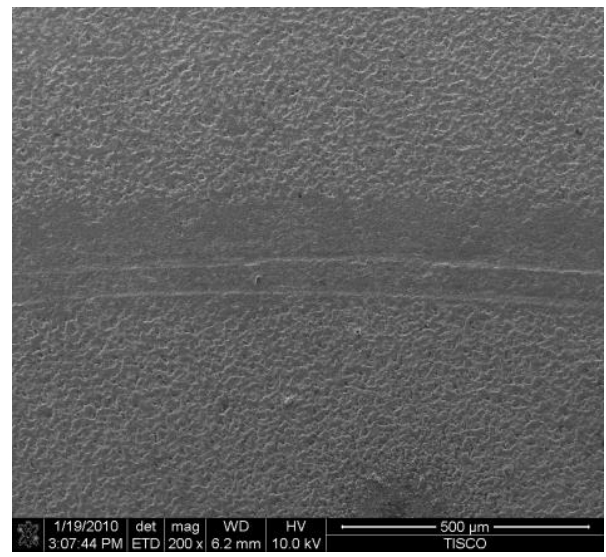

a

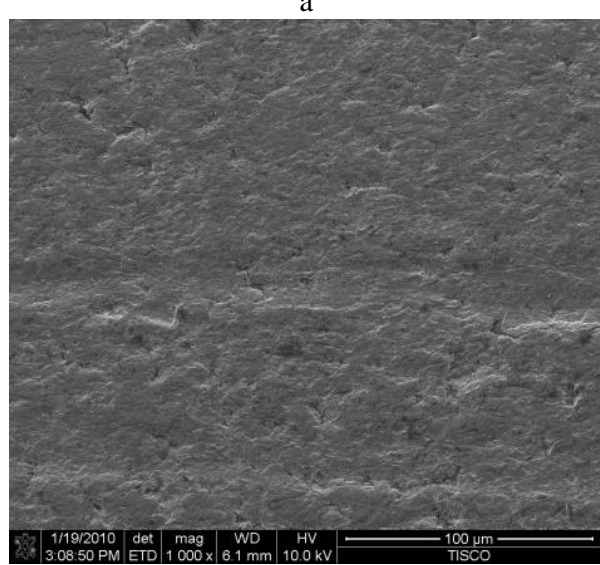

b

Fig. 10. Wear track of TRD treated AISI 52100 steel: a-wear scar morphology of specimen; $b$ - micrograph of wear surface
As shown in Fig. 9 b, AISI 52100 substrate presents grooves parallel to the sliding direction as a result of the heavy ploughing of the counterbody $\left(\mathrm{Si}_{3} \mathrm{~N}_{4}\right.$ ball), and these features indicate the wear mechanism is abrasive wear and adhesion. This is due to the fact that the hardness of 52100 steel is lower than that of the $\mathrm{Si}_{3} \mathrm{~N}_{4}$ ball. In comparison, Fig. $10 \mathrm{~b}$ shows that the wearing of chromium carbide layer is slight, and only some surface asperities are rubbed down. Therefore, the wear mechanism is mainly slight abrasion.

Fig. 11 shows the wear scar profile curves of the AISI 52100 steel substrate and the TRD treated samples. It can be seen that the wear resistance performance of the AISI 52100 steel improves evidently after TRD treatment. The wear volume of the AISI 52100 steel substrate and the TRD treated samples calculated from the wear profile are $1.492 \times 10^{8} \mu \mathrm{m}^{3}$ and $1.583 \times 10^{7} \mu \mathrm{m}^{3}$ respectively, the wear weight loss decreased by $89.3 \%$. $K$ of AISI 52100 steel substrate calculated is $1.842 \times 10^{-5} \mathrm{~mm}^{3} / \mathrm{N} \cdot \mathrm{m}$ according to the formula (1), and $K$ of the chromium carbide layer calculated is $1.954 \times 10^{-6} \mathrm{~mm}^{3} / \mathrm{N} \cdot \mathrm{m}$, the former is about 10 fold of $K$ value of the latter. This suggests that the wear rate is also reduced greatly. There are many reasons for it. One reason is that chromium carbide layer itself has high hardness, low friction coefficient and well anti-sticking property so that the coating has well anti-sticking wear performance and resulting in efficient resisting the intrusion cutting of the mating material. Another reason may be attributable to the high interface bonding strength of substrate and coating.

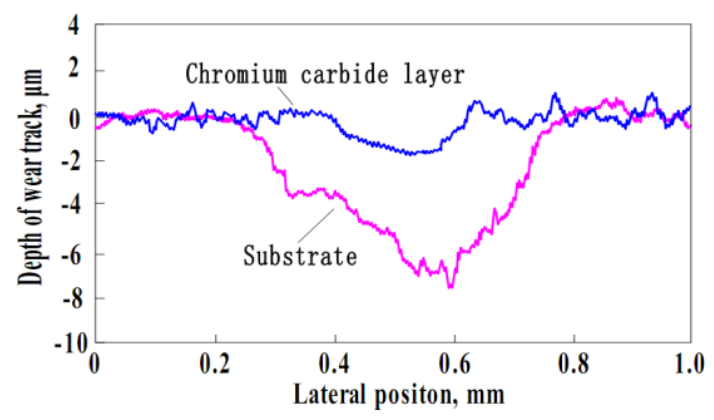

Fig. 11. Wear track profile curves of substrate and TRD treated AISI 52100 steel

\section{CONCLUSIONS}

The following conclusions can be derived from the present work:

1. The chromium carbide coatings produced on the surface of AISI52100 steel had a smooth and flat morphology.

2. The chromium carbide coatings themochemically grown on the AISI52100 steel was comprised of $\mathrm{Cr}_{7} \mathrm{C}_{3}$ and $(\mathrm{Cr}, \mathrm{Fe})_{7} \mathrm{C}_{3}$ phases.

3. the chromium carbide coatings ranged in thickness from 3.2 to $8.5 \mu \mathrm{m}$ versus TRD treatment time. The longer TRD treatment time, the thicker chromium carbide layer is.

4. The microhardness of the chromium carbides layers formed on the surface of AISI52100 steel ranged from 1730 to $1920 \mathrm{HV}_{0.025}$, whereas the Vickers hardness values of the AISI52100 substrate was $723 \mathrm{HV}_{0.025}$. 
The surface hardness of AISI52100 steel was remarkably improved by TRD treatment.

5. The Daimler-Benz Rockwell-C adhesion test result shows that the adhesion strength quality of the chromium carbide layer is related to HF2 to HF3, there were sufficient adhesion of the chromium carbide lays on AISI 52100 steel.

6. The friction coefficient reduced from 0.46 to 0.37 and the wear weight loss decreased by $89.3 \%$ after TRD process, which indicated that chromium carbide layer can significantly improve the wear resistance.

\section{Acknowledgement}

The authors acknowledge the supports provided by the Natural Science Foundation of Hubei Province, China (No. 2017CFB488) and Luoyang bearing Research Institute. They would also like to thank the support of the research project of State Key Laboratory of Materials processing and Die \& Mould Technology and the Analytical and Testing Center of HUST.

\section{REFERENCES}

1. Ghadi, A., Soltanieh, M., Saghafian, H., Yang, Z.G. Investigation of Chromium and Vanadium Carbide Composite Coatings on CK45 Cteel by Thermal Reactive Diffusion Surface and Coatings technology 289

2016: pp. $1-10$.

https://doi.org/10.1016/j.surfcoat.2016.01.048

2. Kulka, M., Makuch, N., Pertek, A., Piasecki, A. An Alternative Method of Gas Boriding applied to the Formation of Forocarburized Layer Materials Characterization 72 2012: pp. 59-67. https://doi.org/10.1016/j.matchar.2012.07.009

3. Biesuz, M., Sglavo, V.M. Chromium and Vanadium Carbide and Nitride Coatings obtained by TRD Techniques on UNI 42CrMoS4 (AISI 4140) Steel Surface and Coatings Technology 286 2016: pp. 319-326. https://doi.org/10.1016/j.surfcoat.2015.12.063

4. Castillejo, F.E., $\quad$ Marulanda, D.M., $\quad$ Olaya, J.J., Alfonso, J.E. Wear and Corrosion Resistance of NiobiumChromium Carbide Coatings on AISI D2 produced through TRD Surface and Coatings Technology 254 2014: pp. $104-111$. https://doi.org/10.1016/j.surfcoat.2014.05.069

5. Richert, M. W., Książek, M., Pałka, P., Wawrzyniak, S., Grzelka, R., Plońska-Niżnik, K. Microstructure Characterisation of Chromium Carbides Coatings deposited by Thermal Spraying Processes Journal of Achievements in Materials and Manufacturing Engineering 55 (1) 2012: pp. $108-112$.

6. Yuan, Z.H., Wang, Z.J., Zhang, W.Q., Wang, Z.J., Duan, X.X. Preparation and Property of Chromium Carbide Thermal Diffusion Coating on Cold Working Die Materials Journal of Wuhan University of Technology 25 (4) 2010: pp. 596-599. https://doi.org/10.1007/s11595-010-0051-x

7. Podgrajššk, M., Glodež, S., Ren, Z. Failure Analysis of Forging Die Insert Protected with Diffusion Layer and PVD Coating Surface and Coatings Technology 276 2015: pp. $521-528$. https://doi.org/10.1016/j.surfcoat.2015.06.021

8. Beake, B.D., Li, N., Gey, C., Veldhuis, S.C., Komarov, A., Weaver, A., Khanna, M., FoxRabinovich, G.S. Wear Performance of different PVD Coatings during Hard Wet End Milling of H13 Tool Steel
Surface and Coatings Technology 279

2015: pp. $118-125$.

https://doi.org/10.1016/j.surfcoat.2015.08.038

9. Douard, A., Bernard, C., Maury, F. Thermodynamic Simulation of Atmospheric DLI-CVD Processes for the Growth of Chromium-based Hard Coatings using Bis(benzene)chromium as Molecular Source Surface and Coatings Technology 203 2008: pp. 516-520. https://doi.org/10.1016/j.surfcoat.2008.07.013

10. Kuo, D.H., Huang, K.W. Kinetics and Microstructure of TiN Coatings by CVD Surface and Coatings Technology 135 (2) 2001: pp. 150-157. https://doi.org/10.1016/S0257-8972(00)00986-5

11. Elias, E.M., Ortiz, D.M., Keddam, M., Gómez, V.O.A. Boriding Kinetics and Mechanical Behaviour of AISI O1 Steel Surface Engineering 31 (8) 2015: pp. 588-597. https://doi.org/10.1179/1743294415Y.0000000065

12. Kurt, B., Küçük, Y., Gök, M.S. Microabrasion Wear Behavior of VC and CrC Coatings Deposited by Thermoreactive Diffusion Technique Tribology Transactions 57 (2) 2014: pp. 345-352.

https://doi.org/10.1080/10402004.2014.880538

13. Orjuela, G.A., Rincóna, R., Olaya, J.J. Corrosion Resistance of Niobium Carbide Coatings Produced on AISI 1045 Steel via Thermo-reactive Diffusion Deposition Surface and Coatings Technology 259

2014: pp. $667-675$. https://doi.org/10.1016/j.surfcoat.2014.10.012

14. Soltani, R., Sohi, M.H., Ansari, M., Haghighi, A., Ghasemi, H.M., Haftlang, F. Evaluation of Niobium Carbide Coatings Produced on AISI L2 Steel Via Thermoreactive Diffusion Technique Vacuum 146 2017: pp. $44-51$. https://doi.org/10.1016/j.vacuum.2017.09.023

15. Yaghtin, A.H., Salahinejad, E., Khosravifard, A., Araghi, A., Akhbarizadeh, A. Corrosive Wear Behavior of Chromium Carbide Coatings Deposited by Air Plasma Spraying Ceramics International 41 (6)

2015: pp. 7916-7920.

https://doi.org/10.1016/j.ceramint.2015.02.131

16. Zarchi, H.R.K., Jalaly, M., Soltanieh, M., Mehrjoo, H. Comparison of the Activation Energies of the Formation of Chromium Carbide Coating on Carburized and Uncarburized AISI 1020 Steel Steel Research International 80 (11) 2009: pp. 859-864. https://doi.org/10.2374/SRI09SP066

17. Yusuf, K., Sukru, T. Characterization and Rockwell-C Adhesion Properties of Chromium-based Borided Steels Journal of Adhesion Science and Technology 29 (19) 2015: pp. $2065-2075$. https://doi.org/10.1080/01694243.2015.1052617

18. Martini, C., Palombarini, G., Poli, G., Prandstraller, D. Sliding and Abrasive Wear Behaviour of Boride Coatings Wear 256 (6) 2004: pp. 608-613. https://doi.org/10.1016/j.wear.2003.10.003

19. Vidakis, N., Antoniadis, A., Bilalis, N. The VDI 3198 Indentation Test Evaluation of a Reliable Qualitative Control for Layered Compounds Journal of Materials Processing Technology 481 2003: pp. 143-144. https://doi.org/10.1016/S0924-0136(03)00300-5

20. Fan, X.S., Yang, Z.G., Zhang, C., Zhang, Y.D., Che, H.Q. Evaluation of Vanadium Carbide Coatings on AISI H13 Obtained by Thermo-reactive Deposition/Diffusion Technique Surface and Coatings Technology 205 (2) 2010: pp. 641-646. https://doi.org/10.1016/j.surfcoat.2010.07.065 